\title{
Do you SEE the Words Coming out of that Text?: Seeing Whiteness in Digital Text
}

\author{
Cheryl E. Matias \\ University of Kentucky \\ U. S. A.
}

ABSTRACT: Though texts are commonly perceived as merely written, this article explores texts in a more complex manner: in digital form. First, the paper posits the importance of "reading" digital texts (e.g., social media, films, memes, etc.) and demonstrates how such texts transmit hegemonic ideas about race and whiteness, which ultimately reifies white supremacy in society.

Using a variety of critical theories such as critical studies of whiteness and critical theories of race, this article deconstructs digital texts (particularly film and social media) to demonstrate how whiteness gets embedded in digital text in almost invisible ways. Additionally, this article employs Yosso's (2002) critical race media literacy (CRML) not only to divulge racial stereotypes in digital texts but also to demonstrate how CRML can be pedagogically and metacognitively applied to reveal how whiteness also gets embedded in digital texts. This article serves as a metacognitive model as to how readers can learn to read whiteness within digital texts.

KEYWORDS: Digital text, media, critical race media literacy, whiteness, pedagogy

\author{
Introduction: "Texts," Race, and Whiteness, and a Pedagogy to See \\ Critical Race Media Literacy \\ Seeing Whiteness in Society \& Digital Texts \\ Seeing Whiteness in Pedagogy \\ Conclusion: Hindsight \\ Notes \\ References
}

\section{Introduction: "Texts," Race, and Whiteness, and a Pedagogy to See}

"Texts" of today go beyond the written word or any form of traditional print media. As Kellner (1995) offers, texts consist of "radio, film, television, music, and print media" (p.1). However, in an ever-increasing post digital era (see Jandrić, et al., 2019), texts nowadays also include social media, viral videos, gifs, tweets and posts, pictures, memes, vines, and much more. Beyond the simple text itself, meaning can only be derived when considering more complex relationships between the text and the reader. For example, to better comprehend the meaning behind texts, one must also understand the interpellation between the text to that of the real world wherein the text resides or between the subjectivities of what is 
"written," who wrote it, who reads it, and the given society that structures their subjectivities. As Ahmed (2004) poignantly describes in her analysis of the sentiment of racial fear between Black and white ${ }^{1}$ subjects,

Fear signified through language and by the white body does not simply begin and end there: rather the fear works through and on the bodies as those who are transformed into its subjects, as well as its objects. (p. 63)

Clearly, texts become much more than what is simply written down in any medium. Therefore, deeply understanding the given society of where that text is posted is an essential component in properly understanding any given text. Given this, Sandoval (2000) reminds us that superpower nations like the U.S. are nonetheless "neocolonizing postmodern global formations" (p. 2) which then cannot be understood outside a capitalistic apparatus (see Althusser, 2006). Be that as it may, there exists "subjection to the ruling ideology" of how U.S. society is divided between the haves and have nots based on capitalistic ideology (p. 88).

Furthermore, insomuch as the U.S. has a capitalistic apparatus that subjects individuals to a capitalistic ideology, so much so that it often goes unnoticed, so too is there a racial apparatus that so embeds itself in the depths of U.S. racial ideology that it often goes unnoticed. In fact, the ideology of race is, at times, so unnoticed that some individuals erroneously believe it is not real. Leonardo (2005) refers to this as racial state apparatus (RSA), something that so inoculates U.S. racial ideology that it presumably becomes almost invisible, merely a fleeting social construction. However, Leonardo warns us that race cannot be "reduced to mere chimerical status devoid of material underpinnings" (p. 409). To provide an example, Leonardo proposes that American schools are, in and of themselves, institutionalized material byproducts of the RSA. Therefore, race, texts, schools, and society can never be divorced from each other.

Herein lies the quandary. How then are readers to "read" ever evolving digital texts of a given white supremacist society that refuses to acknowledge its historical roots of race? That race is a real construct that reaps real material benefits is not contested here. Alas, that much is understood. What is not clearly understood, however, is if the overarching issue of race, meaning ideology of whiteness, is so entrenched in a given society that its presence is barely recognized, then how does one read racial messages, especially with respect to the ideological dominance of whiteness, behind digital texts in a racially just manner? This article attempts just that. Instead of further masking the latent or subliminal messages of race and whiteness in modern day digital texts, this article pedagogically reveals whiteness in a way that provides a metacognitive schema of learning how to decipher codes of whiteness.

\footnotetext{
${ }^{1}$ In order to pay homage to Critical Race Theory and Critical Whiteness Studies I strategically lowercase the "W" in white(s)/whiteness to decenter its racial stronghold.
} 
This article theoretically draws from critical studies of whiteness such as Cheng's (2001) psychosocial analysis of Asian American actors represented in white films or Vera and Gordon's (2003) media analysis of whiteness in Hollywood films, critical theories of racial semiotics (e.g., Sarah Ahmed and Chela Sandoval), and critical media literacy (e.g., Douglas Kellner) to better understand how messages of whiteness are transmitted through digital texts and how that process then educationally misinforms society about the role race has in U.S. contexts. Additionally, this article rhetorically applies Yosso's (2002) critical race media literacy as a method to investigate the embedded whiteness in U.S. digital texts so that learners can see whiteness more clearly. In an increasingly multicultural digital world, never has there been more need to understand how racial dominant ideologies of whiteness get transmitted worldwide.

\section{Critical Race Media Literacy}

Kellner (1995) describes media culture as "spectacles" much like critical theorist DeBord's (2006) assertion that spectacles are the "main production of present-day society" (p. 120). Meaning, media culture houses an assemblage of images, ideologies, and rhetoric already circulating in a given society, a society already structured by various institutional powers. That is, media culture is political in that the media "demonstrate who has power and who is powerless, who is allowed to exercise force and violence, and who is not. They dramatize and legitimate the power of the forces that can be and demonstrate to the powerless that if they fail to conform, they risk incarceration or death" (DeBord, 2006, p. 2). Therefore, unlike in popular thought which sees digital texts (within media culture) as simple transmissions of existing ideas in a given society, digital texts also have the capacity to reinforce the existing power structure of said society. With respect to this article, the hegemonic ideology of whiteness is in constant competition for racial power and thus cannot be divorced from the digital texts produced within a white supremacist society.

As Yosso (2002) offers, "The ideology of racism creates, maintains, and justifies the continual production of entertainment media images" (p. 53). Needless to say, racism and whiteness inoculate digital texts and are at the same time mediated through digital texts. Therefore, to be critical of digital texts Yosso (2002) offers critical race media literacy (CRML) because it "challenges educators to develop a theoretical, conceptual, and methodological strategy to examine how the intersections of racialized subordination inform Chicana/o entertainment media portrayals" (p. 54). Furthermore, I contend that such portrayals extend outward to include not only Chicana/s/Latinx populations but also Black/African American, Asian American Pacific Islanders, Muslim and Middle Eastern Americans, and other racialized groups. In the end CRML has the capacity to "not only question the media images but to also take action to change such portrayals" (p. 56). As such, though critical media literacy is a pedagogical method to facilitate racialized image deconstruction, it also serves to undergird racially just activism. In Yosso's (2002) study of the effects of including a critical race media curriculum, students "bec[a]me angry" with the racial stereotypes of Latina/o students as lazy, 
unmotivated for educational attainment, so much so that they "def[ied] the odds and succeed[ed] in their educational and career goals" (p. 58). Clearly, CRML heightens racial awareness while cultivating a motivating force that compels viewers (or readers of those particular digital texts) to reject stereotypes that negatively impact their communities and lives.

Based on the above, I strategically apply Yosso's (2002) notion of critical race media literacy as a method for analysis. Since digital texts "must be contextualized within power relations," they "therefore must focus on racism, sexism, and classism" (p. 59). In fact, Yosso further contends that "media literacy research that fails to address racism as an inextricable, central component to the commercial globalization of media limits the potential of its own pedagogy" (p. 59). Notwithstanding this, I deliberately apply Yosso's notion of CRML as a formidable method by which one can deconstruct race and whiteness in film. However, instead of applying CRML within a class setting where Chicana/o students respond to key critical race questionings--as did Yosso--I draw from my classroom teaching experiences and rhetorically apply those same lines of questions to demonstrate here how such a pedagogy can also be employed to build a new metacognitive racial schema for one's self. That is, instead of asking students to respond to clips and then methodologically reporting on their responses here, I will draw upon some of the similar questions Yosso provides in her text to metacognitively think through (albeit thinking out loud) the embedded whiteness in digital texts. With respect to this article, I focus particularly on how whiteness both embeds itself and mediates through digital texts as a way to not only reflect but also maintain white supremacy in society.

Following are a few of the critical race media questions Yosso (2002) provides to help guide the "reader" through a greater race comprehension. Who/what do these images portray? What purpose[s] do these images serve? Why do you think filmmakers included these images as a part of the story? What influence do your own theories have as you "read" the images? What would you do differently if you could remake these images? Is this scene a reflection of real life? (Yosso, 2002, pp. 55-57). Throughout this article I reflect on my own teaching practices that mirror this Socratic-like questioning; however, I also apply such questions to my own metacognitive schema on race so that I can make better sense of how whiteness is disseminated through digital texts within my own life.

\section{Seeing Whiteness in Society \& Digital Texts}

Of the many characteristics of whiteness, it is the characteristic of invisibility that not only maintains its power but also gives whiteness its strength. Dyer (2008) corroborates this by claiming that "the invisibility of whites as a racial position in white (which is to say dominant) discourse is of a piece with its ubiquity" (p. 11). It is this seemingly naturalness of how whiteness operates that obscures its true deleterious nature. Even worse, people have become so habituated to this racial state apparatus (cf. Leonardo) that they neither question nor are fully cognizant of it. 
Take, for example, an exercise I do in my teacher preparation graduate course using a clip from the 2004 Hollywood film Crash. In the clip Ludacris (a Black male) "schools" ${ }^{2}$ " Lorenz Tate (a Black male) about the racial oppression of Black men in U.S. America. Though Ludacris drops knowledge about how white America responds to Black men, both men end up, at the end of the scene, robbing a white couple (actors Sandra Bullock and Brendan Fraser). When I ask my students what messages about race were transmitted in this film, they are quick to recognize the hypocrisy. That a "woke" Black man explains his racial plight within a white supremacist society only to have his character reduced down to nothing more than another Black male stereotype of a violent criminal is quickly seen. My class talks about these Black male stereotypes, how racial realism is laughed away via Lorenz Tate's character, and how intersections of race and class, or as Leonardo (2012) terms it, raceclass ${ }^{3}$, are reproduced in the film.

After listing these learnt findings on the board, rarely does anyone say anything about how whiteness was portrayed. But what of whites? What does the clip say about white people and whiteness? Cheng (2001) argues that the focus on racial stereotypes is a common maneuver in films.

The introduction of the racial stereotype must therefore always bring into question the unquestionable realness supposedly untouched by the stereotype, the "original real," what the stereotype supposedly cannot speak to: whiteness itself." (p. 41)

As viewers read these messages about racial stereotypes in films, even if--as in this clip--they try to thwart such stereotypes, films ultimately reinforce them by allowing such performances of the stereotyped behaviors. Moreover, by reinforcing stereotypes they also divert the viewers' attention away from the latent existing condition of whiteness, which serves as the backdrop of promoting stereotypes. This means that a digital text such as a film that represents stereotypes "marks a disturbance in its supposed fixity. And the problem of truth (and authentic representation) boomerangs back to whiteness itself" (Cheng, p. 40). As viewers "read" these "racial masks to both veil and authenticate whiteness," they inadvertently overlook how much "whiteness has played a persistent role in the process of Americanization" (p. 42).

Again, the seemingly normality of whiteness is what troubles me most as a teacher educator precisely because the transmittal of whiteness is a pedagogy of teaching whiteness. To be blunt, digital texts like films have the pedagogical capacity to teach the hidden curriculum of whiteness. Vera and Gordon (2003) caution viewers, saying that "we are the result of the images, stereotypes, and knowledge used to define us and constitute us as human beings" (p. 2). Just as

\footnotetext{
${ }^{2}$ U.S. slang for strongly teaching someone about something.

${ }^{3}$ Leonardo (2012) argues that race cannot be analyzed without an intersection of class and vice versa. Hence, one word that intertwines two concepts.
} 
the clip discussed earlier misinforms viewers about the images and stereotypes of Black men, it also misinforms viewers about the images and messages of whites and of whiteness, ones we, as a society, then use to define ourselves. This phenomenon is no different than the Kenneth and Mamie Clark (1939-1940) doll study in which 3-year-old Black children indicate that the Black doll is considered the "bad" doll and that they too are the Black doll. Clearly, internalizing the messages within digital texts can become a dangerously inhumane game when the messages are controlled by a racial state apparatus of whiteness.

In the film clip from Crash, Bullock and Fraser are a white couple who are depicted as innocent, victims, and wealthy. With respect to the entire clip, the messages of whiteness that are then transmitted are that Blacks, or more generally Black, Indigenous, People of Color (BIPOC), are the ones preoccupied with race and that whites are racially innocent of it all. Since they (Bullock and Fraser) were not talking about race and were then robbed by Black men (Ludacris and Tate) who were discussing the role of anti-Blackness in a white supremist society, they (Bullock and Fraser) are perceived as the "true" victims of racism, presumably simple bystanders of racially motivated Black males. What purposes do these images serve? Pedagogically applying Yosso's (2002) line of questioning, one cannot help but see how long-held beliefs of Black male violence are upheld. These exact stereotypes are what undergirded legal rulings such as U.S.- based anti-miscegenation laws. This ideological imagery is furthered because Bullock is depicted as not having any racial motivations behind tightening her grip on her purse and pulling her husband closer upon seeing the two Black men. This transmits the message that white women who have engaged in similar behaviors as Bullock are absolved from any racial implications.

Furthermore, Tate even vouches for Bullock, saying she simply grabs her purse and husband because she is cold and not because of race. And, in doing so, he is depicted as the more sensible character of the two Black men. This then imparts the ideological imagery of whiteness that Blacks who downplay race in their lives are generally thought of as more sensible (e.g., Candace Owens), but in the end are still as dangerous as Blacks who speak out about racism. And, since whiteness is about silencing its own mechanisms, white America will then prefer the more "sensible" characters of Color who never bring up race while simultaneously feeling righteous in their self-imposed fear of them.

Furthermore, just as the transmission of messages through digital texts is important to fully comprehending digital texts, so too is acknowledging the existing society from which such text is transmitted. Vera and Gordon (2003) state, "We need to study movies not only because of what they tell us about the world we live in but also, and most importantly, because movies are a crucial part of that world" (p. 8). That being said, digital texts reside within an existing society that reflects particular ideologies that are not exempt from competing power structures. The movie Crash, which takes place in Los Angeles, came out in 1994 and was heralded as the most critical movie about race of its time. However, the real-life movie about race was playing out in Los Angeles in the 1990s. From growing racial tension post the Rodney King beating to the L.A. riots, race was plastered on 
national media. However, the video footage of BIPOC looting stores or the nationally publicized beating of Reginald Denny, a white truck driver, by Black men eclipsed the long-term story of police brutality, racial discrimination and harassment, and race-based poverty on people of Color, primarily on Black folks. This message is no different than today when the message of the \#Blacklivesmatter protest worldwide is thwarted or obscured because of rioters, looters, and white supremacists using the movement and protests as a means to justify racial war, anti-government actions, or anarchy altogether. In doing so, naysayers of the BLM movement can justify their decision to turn a blind eye to the history of police brutality as a sad way to absolve their own anti-Black anxieties. Just as Cheng (2001) argues, by positioning the reader's attention on the atrocities performed by people of Color, it ultimately diverts attention away from the longterm historical atrocities of whiteness and white supremacy on people of Color. Plainly, the looters and rioters are NOT the issue: anti-black racist attitudes embedded in whiteness ideology are.

As such, digital texts can erroneously relay the message that the "real" story of race was not about white cops beating on Black men like Rodney King anymore, nor about the centuries of policing and terrorizing Black bodies, white supremacist institutions that regulated access to employment, education, and housing through racial discrimination and harassment, and through legal sanctions and policies that strategically limited the freedom of people of Color in total. No. Instead, digital texts, like the one from Crash, redirect the focus of racial tension away from how systemic institutions of white supremacy have long discriminated on people of Color to how people of Color commit violent acts against innocent whites. In fact, such texts attempt to reduce systemic racism down to individual acts once again, claiming that Blacks can be racist to whites and twisting reality by claiming that the "real" racial tension is between Blacks and Korean Americans in Los Angeles not that of whites who bask in white privilege. In the end, digital texts resituate dominant society's thoughts on whiteness:(a) that whiteness is ever innocent of racial implications,(b) that whites are the "true" victims of racially motivated crimes, and (c) that since people of color are violent towards whites, it then justifies their maltreatment.

Insomuch as such a movie clip or film is mediated through and by society, so too are social media posts, responses, photos, and blocking. To illustrate this I draw from a recent post a friend shared on social media to help promote a new book entitled Surviving Becky(s): Pedagogies for Deconstructing Whiteness and Gender 


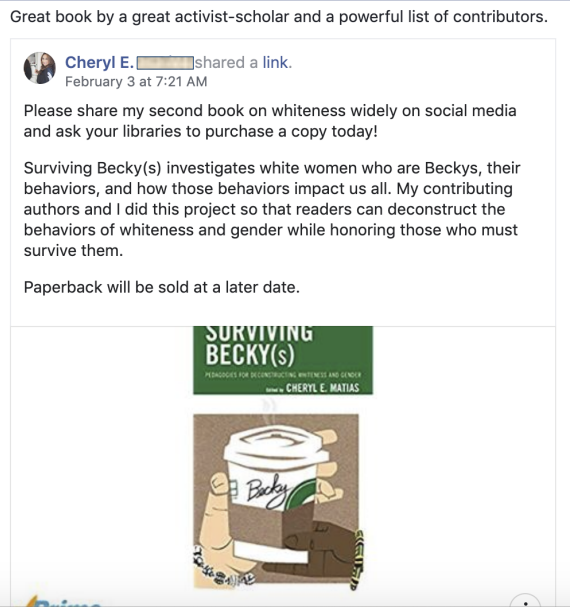

As seen in the post, there is a description of the book and how it "investigates white women who are Beckys." Note that the terminology "Becky" is nothing new. In fact, it has been an increasingly commonplace phrase used to denote a white woman who is unaware of her privileges but engages in racist ways ${ }^{4}$. National press like USA Today published what is a Becky ${ }^{5}$, online articles went viral about what types of Beckys are out there ${ }^{6}$, and even viral memes have been spread about various types of Beckys, like BBQ Becky ${ }^{7}$. Clearly, the Becky phenomenon is not new, much like the Central Park Karen ${ }^{8}$. By the time my book was announced on a Facebook Group named "Teaching Social Justice Resource Exchange" that already had posts about white supremacy, articles on white privilege, and racial justice, one would think that members of this group would have already had exposure to the up-to-date conversations about race and whiteness. Yet, despite this, once my book was posted a white woman named Rebecca (no pun intended) started posting comments about her reaction to the posts:

Rebecca W...... Why are you picking on us ? I'm a Beckie and doubt if I fit any of your stereotypes. So far to the Left lifelong Peace Activist Environmentalist Vegan Go to Hell Like - Reply $\cdot 1 w$

Rebecca $\square . \ldots \ldots$ There's a lot of girls names Like · Reply $1 \mathrm{w}$

Rebecca $\square$ I also have fought all my life for Civil Rights my soul is black

Like - Reply - 1w

${ }^{4} \mathrm{https}$ ://en.wikipedia.org/wiki/Becky (slang)

${ }^{5}$ https://www.usatoday.com/story/life/entertainthis/t'/2016/04/27/what-does-becky-meanheres-history-behind-beyoncs-lemonade-lyric-sparked-firestorm/83555996/

${ }^{6}$ https://www.theroot.com/the-five-types-of-becky-1798543210

7 https://heavy.com/news/2018/05/jennifer-schulte-bbq-becky/

8 https://nypost.com/2020/05/26/central-park-karen-says-life-is-being-destroyed-over-viral-video/ 
With respect to metacognitively applying critical race media literacy Yosso (2002) questions, "What purpose(s) do these images serve?" (p. 55). Before that can be answered I reveal what messages are being transmitted from a post like that. For one, notice how the comments take on a personal tone unlike all the comments beforehand (see example below).

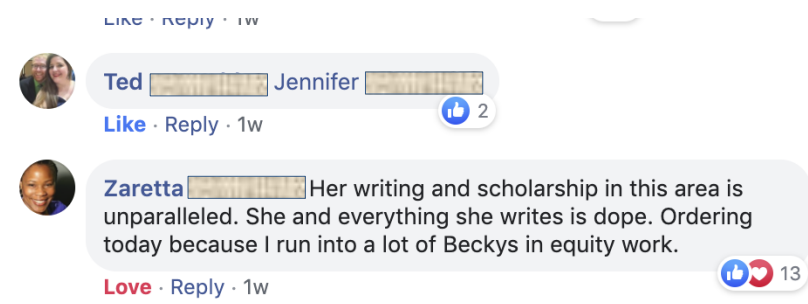

Instead of talking in third person, Rebecca internalizes the book and quickly gets into the defensive by insinuating, "Why are you picking on us?" What purpose does this serve? This seemingly simple phrase serves many functions in whiteness, but before I get into them it is important to note that the original post has my picture on it; thus, Rebecca is clearly aware that the book is written by a woman of color. Additionally, with respect to Rebecca who has a headshot of her face on her Facebook profile, it is clear to all that she is a white woman. However, the person who shared my original post is a white male who is well known for his work on racial justice. In fact, the Facebook group where this post was shared is administered by him. Despite this, the comments are directed towards me as the author of the book and take on a personal and accusatory tone. In doing so, the purpose is to isolate the POC who is being attacked, individualize the racist treatment, and structure the entire narrative by placing Becky as the victim while refusing to own up to her aggressive attacking behaviors. This is no different than the Central Park "Karen" who creates a false narrative of her being "attacked" by an "African American man" when she was the aggressor of the entire racial incident. Again, it serves to isolate the real victim of racism, individualize the racism, and structure a narrative of victimhood.

What do these images portray? Quickly assuming victim status as a white woman, Rebecca's accusation of another woman of color being "aggressive" to a helpless white woman is quickly invoked. That is to say, Rebecca clearly gaslights the entire comment thread to posit that she is a victim being picked on by a bully, something that no one else in the comment thread states. In fact, there were many other white women on the thread discussing the book itself, none who internalized the book title for they knew not to judge a book by the cover. One woman, also named Becky, even joked about the name Becky in the title of the book:

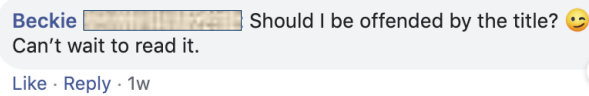

However, Rebecca changed the discourse to center herself as a victim when no one else saw themselves as victims, even those who bore the same name. So, 
when Rebecca begins her comment about "Why are you picking on us?" she quickly determines who the victim and who the aggressor are even though such labeling was not there in the first place.

Why do you think she included this phrase as part of the story? Though this posting and its threaded comments are not a regular film with a storyline, Rebecca is starting a storyline herself, one that has now identified a protagonist and an antagonist. But that's not all of the story. For Rebecca to quickly jump in on the defensive is not unusual with regards to white fragility (see DiAngelo, 2018) or white emotionalities (see Matias, 2016); however, what is interesting is that she does so in a unique, racial-gendered way. That is to say, she is not only being defensive in that mere question; she is also positioning herself on widely held ideologies of whiteness and gender: that of white women's innocence (see Matias, 2020). Clearly, she is drawing from hegemonic ideas of whiteness and gender of white women as innocent to justify her defensiveness while ironically invoking victimhood at the same time. That is, she is the one who is acting aggressively by directly engaging in a public confrontation yet does so under the stereotypes that I, the woman of color who simply wrote the book, am the one picking on white women. I do not know this woman; my colleague was simply sharing my new book. And yes, the book focuses on white women just as there are many books written by white authors who focus on Latinos/Latinx/Chicanos, African Americans/Blacks, Asian American Pacific Islanders, Muslims, etc., etc., etc. In fact, white authors writing about other cultures has been undertaken for so long that finally folks of color are in a socio-political climate such that they are fighting back to reclaim their narrative. This can be seen in the national backlash to American Dirt ${ }^{9}$--a Mexican American story written by a white female or the movement to \#citeBlackwomen ${ }^{10}$. Frankly speaking, BIPOC are tired of white women bogarting or Colombusing ${ }^{11}$ the narrative of communities of color.

To be clear, historically speaking, authors are oftentimes also the victors and thus their characterizations of BIPOC as lazy, indolent, savages, and/or uncivil were strategically used to gain political power, land annexation, and justify inhumane treatment. That there exist books that now focus on white women written by a woman of color was too much for Rebecca to bear. As such, she reverts to the old tactics of being a victim, hoping her tears would garner enough support as such tears have done in the past. In doing so she hopes such support will then attack me, the woman of color, just as white women's tears have attacked Emmett Till or the Central Park Five. Clearly, she is setting up the recycling of a good ole' white story.

${ }^{9}$ https://www.latinousa.org/2020/01/29/americandirt/

$10 \mathrm{https} / / / w w w . c i t e b l a c k w o m e n c o l l e c t i v e . o r g /$

${ }^{11}$ https://www.npr.org/sections/codeswitch/2014/07/06/328466757/columbusing-the-art-ofdiscovering-something-that-is-not-

new\#: : :text=Columbusing $\% 20$ is $\% 20$ when $\% 20$ you $\% 20 \% 22$ discover,even $\% 2 \mathrm{C} \% 20$ say $\% 2 \mathrm{C} \% 20 \mathrm{y}$ our\%20neighborhood. 
By operationally using the word, "us" in the question, Rebecca successfully garnered support. She did not say, "Why are you picking on me?" Instead she strategically used the word us to identify a racial and gendered polity. In fact, this prompts another white woman to say she's also offended. This second Becki then goes around the entire comment thread to post subtle slights on everyone else's comments (see below).

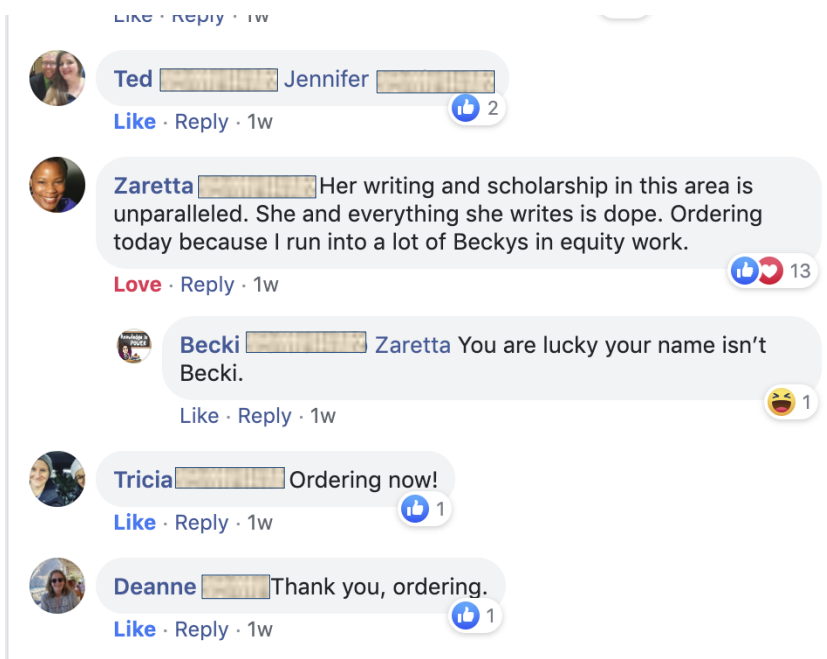

What do these images portray? So far, the imagery of this entire digital text is that, by virtue of writing a book on white women, I am perceived as a bully to white women, an accusation rarely given to white authors who write about cultures not of their own. In fact, during a time of national backlash to American Dirt, never once is the white woman author accused of being a bully. Instead she is accused of using racial stereotypes of a culture she is not familiar with (alongside her white privilege in being able to write such a book) and getting seven figures for it.

Furthermore, these white women start to gaslight the entire purpose of the book. Despite the fact that the book is about pedagogies for deconstructing whiteness and gender in popularized characterizations of the national phenomenon of Becky, they reposition the imagery of the book as using stereotypes of white women. Interestingly, these white women attempt to align their argument with the Latino community in their outcry of American Dirt. Rebecca states, "I'm a Beckie and doubt if I fit any of your stereotypes," while the other Becky also assumes the book uses stereotypes. Of course, these comments were made without ever reading the book. So, though there are claims of my prejudging white women, they themselves are prejudging the entire book without ever reading it. And, yet they can do so because they operate in white privilege. Again, this aligns with whiteness ideology, in that in a white supremacist society whites need not have any qualifications to actually identify race or racism, especially with respect to claims that they do not see race at all, and yet they usurp the power to be the Determiner of what is and is not racist. Like aforementioned above, shifting the focus on their victimhood diverts attention away from the real victims of racism 
and whiteness: BIPOC. In fact, the book Surviving Becky(s) are stories of survival from BIPOC who endure these racially motivated behaviors of white women.

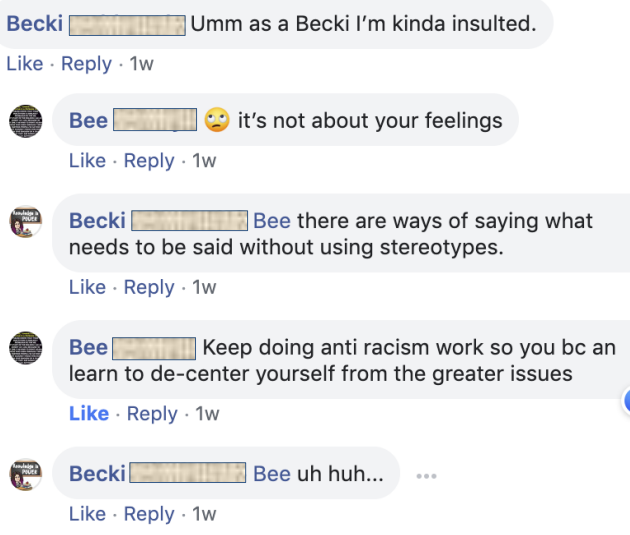

Similar to Yosso's (2002) students, other women (white and of color) on the comment thread were getting angry. Some were aware that these two Beckys were redirecting the focus on how this book is about amplifying the voices of folks who survive white women's behaviors to coddling all white women because these two white women have repositioned themselves as victims. Some lashed back saying, "It's not about your feelings." Others also chimed in with, "Are you for real Becky?" Some even said these Beckys really needed to read the book. Beyond all the comment exchange, there are two main operations of whiteness that are happening here. First, instead of focusing on the book, which is why it was posted in the first place, comments are now fixated on coddling, rejecting, or arguing with the two Beckys. Second, in doing so, whiteness prevails. In fact, it centers itself yet again. With respect to Matias (2016), whiteness is all about narcissism because whenever people talk about racism and the impacts it has on BIPOC, the white reaction comes right out of the common play white handbook of white behaviors: make it all about whites and how much antiracism they have engaged in. For example, see the common phrase pairings.

\begin{tabular}{|l|l|}
\hline Speaker & White Responder \\
\hline $\begin{array}{l}\text { "I'm hurt when you presumed I didn't speak } \\
\text { English." }\end{array}$ & "Why are you making me feel bad?" \\
\hline "People of color experience racism." & "Well, Irish people also did too?" \\
\hline "Racism is real." & "I have a Black best friend." \\
\hline
\end{tabular}


\begin{tabular}{|l|l}
\hline "Black lives matter" & "What about my life?"
\end{tabular}

Notice the semantic recentering of whiteness. It is as if these responders refuse to listen and then usurp their power in whiteness by gaslighting the entire conversation. In fact, this precise display happens with Rebecca when she recenters herself by saying, "I also have fought all my life for Civil Rights my soul is black." In fact, she pontificates this in a public space as a way to absolve her racist behaviors earlier.

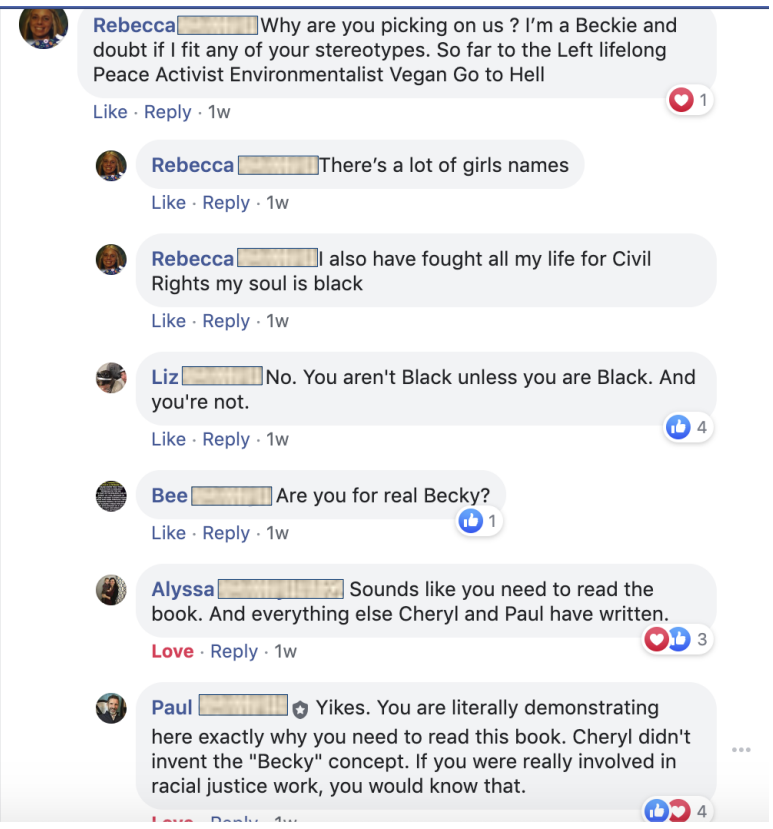

In the end the entire story plays out on digital text and the message is clear. Whiteness is not only reflected in the text itself; it is mediated within society too. As much as Rebecca and Beckie reflected societal whiteness, the interplay between them, other commenters, and those who are reading the commentary are now impacted by whiteness and thus are subjected by it. Digital text both reflected whiteness and was used as a vehicle to maintain it. Be that as it may, the digital text itself reified whiteness in an already white supremacist society. The digital text becomes, as Foucault (1980) so poignantly posits, a vehicle of power.

\section{Seeing Whiteness in Pedagogy}

The above examples are but two small examples of how whiteness and race embed themselves within digital texts and work through that same media to reinforce white supremacy in society. Notwithstanding this, educators and people in general, who are committed to antiracism or racial justice in any form, must take a critical look into the digital text they absorb every day. Metaphorically speaking, since the power of whiteness is to exist in its presumed sense of normality-as if 
the white background is normal-we need to put on our lens of whiteness, so to speak, to better see how the white background structures the colors all around it. By doing so, we can better realize that white supremacist ideas, no matter how long they have been in place or how habituated one is to them, are no longer normal. Essentially, building a critical race media literacy means we need to make the normal abnormal because it is never a normal practice of humanity to engage in racist behaviors. The questions Yosso (2002) poses are just a beginning. Ask yourself, whom does this benefit and why, or how does portraying the message in this way support normalized ideas about whiteness? The trick here is to not simply digest any digital text but to take a moment to taste its bitterness, sweetness, sourness, saltiness, and umami-ness. When we do, we realize there is much more to swallow.

Beyond reading texts (many of which I cite here) or taking a class on race and media (like the one I offered in the summer of 2020 at University of Kentucky), folks committed to seeing whiteness in digital text must be ready to be uncomfortable, because seeing beyond the background whiteness brings new colors never explored before. One must be prepared to consider why it is that one calls "those" types of films Black films and not just films, or why Crazy Rich Asians still doesn't rock the boat on whiteness and capitalism. Why do you watch, observe, or read certain digital texts and avoid others? Why are you comforted in one genre of ideas as opposed to another? Oftentimes, I bear witness to how white people feel more comfortable talking about race with other whites, similar to how whites like films that depict white saviors of BIPOC. The questions then are why is that comforting? And for that matter, how is finding comfort in the normalized rhetoric of whiteness also very disturbing? Stopping to think about what comforts and discomforts us with regards to race and whiteness is a necessary step before engaging full-heartedly in any project of racial justice, because not until the eye of the beholder changes its view can one more clearly see what one formerly chose to deny.

\section{Conclusion: Hindsight}

Digital texts, in and of themselves, are not benign reflectors of society. Alas, they have the power to not only transmit messages of whiteness; they can also reify the existing power structures of any given society. And what makes digital texts even more dangerous is the readers' inability to decipher how whiteness transmits, interacts, and racially interpellates among the reader, the writer, and the society. In fact, just as whiteness gains its power through its invisibility in society, so too does it gain power when it renders itself unseen in digital text. When people lack pedagogical strategies to rethink what they thought they know about race, inclusive of understanding the invisible operations of whiteness, they then, unfortunately, fall victim to whiteness. And in this interpellation, whiteness gains strength yet again. However, with the use of Yosso's (2002) critical race media literacy and with further theorizations of whiteness, readers are able to see a new text, one that does not so easily blend in with the whiteness of its pages. 


\section{Notes}

Special Note: To readers, may you always see beyond the whiteness on white pages are hear the whiteness midst white noise.

\section{References}

Ahmed, S. (2004). The cultural politics of emotion. Routledge.

Althusser, L. (2006). Ideology and ideological state apparatuses (Notes towards an investigation). The anthropology of the state: A reader, 9(1), 86-98.

Cheng, A. (2001). Melancholy of race. Oxford Press.

DeBord, G. (2006). The commodity of the spectacle. In M. Durham \& D. Kellner (Eds). Media and cultural studies. Blackwell Publishing.

DiAngelo, R. (2018). White fragility: Why it's so hard for white people to talk about racism. Beacon Press.

Dyer, R. (2008). "The Matter of Whiteness" in P. Rothenberg (Ed). White Privilege: Essential Readings on the other side of racism. New York, NY: Worth Publishers.

Foucault, M. (1980). Power/Knowledge. Vintage Books.

Jandrić, P., Ryberg, T., Knox, J., Lacković, N., Hayes, S., Suoranta, J., \& Smith, M. (2019). "Postdigital dialogue." Postdigital Science and Education 1 (1), 163-189.

Kellner, D. (1995). Media culture. Routledge.

Leonardo, Z. (2005). Through the multicultural glass: Althusser, ideology and race relations in post-Civil Rights America. Policy Futures in Education, 3(4), 400-412. https://doi.org/10.2304/pfie.2005.3.4.400

Leonardo, Z. (2012). The race for class: Reflections on a critical raceclass theory of education. Educational Studies, 48(5), 427-449.

Matias, C. E. (2020). Surviving Becky(s): Pedagogies for deconstructing whiteness and gender. Lexington Books.

Matias, C. E. (2016). Feeling white: Whiteness, emotionality, and education. Sense Publishers.

Sandoval, C. (2000). Methodology of the oppressed. University of Minnesota Press.

Vera, H., \& Gordon, A. (2003). Screen saviors. Rowman \& Littlefield.

Yosso, T. J. (2002). Critical race media literacy: Challenging deficit discourse about Chicanas/os. Journal of Popular Film and Television, 30(1), 52-62. 


\section{Author Contact}

Cheryl E. Matias, Cheryl.matias@uky.edu

University of Kentucky, College of Education

Department of Curriculum and Instruction

Dickey Hall, 251 Scott St., Office 335

Lexington, KY 40508 